\title{
Muuntogeeniset kasvit ja viljelijöiden eettiset arvot
}

\author{
Irene Vänninen ${ }^{1}$, Helena Siipi ${ }^{2}$, Marjo Keskitalo ${ }^{1}$, Maria Erkkilä ${ }^{1}$ \\ ${ }^{1}$ Maa- ja elintarviketalouden tutkimuskeskus, Kasvintuotannon tutkimus, 31600 Jokioinen \\ ${ }^{2}$ Turun yliopisto, Filosofian laitos, Assistentinkatu 7, 20014 Turun yliopisto
}

\section{Tiivistelmä}

GM-kasveihin ja niiden viljelyyn kohdistuu voimakkaita asenteita, joista osa pohjautuu viime kädessä eettisiin arvoihin. Kuluttajien eettisten arvojen vaikutusta heidän suhtautumiseensa muuntogeenisiin kasveihin on tutkittu selvästi enemmän kuin viljelijöiden. Ehkä siksi, että muuntogeenimyönteisten viljelijöiden katsotaan olevan tästä teknologiasta potentiaalisesti hyötyvien joukossa. Viljelijät ovat GM-kasvien käyttöönotosta päättäessään kahden tulen välissä: yhtäältä heitä työntävät kohti teknologian käyttöönottoa sen potentiaaliset taloudelliset tai viljelytekniset hyödyt, toisaalta heidän on otettava huomioon kuluttajien GM-kasveja koskevat mielipiteet, jotka ovat Euroopassa paljolti muuntogeenikielteisiä tai -kriittisiä.

Kirjallisuustutkimuksen avulla perehdyttiin viljelijöiden eettisten arvojen rooliin heidän päättäessään muuntogeenisten kasvien viljelyn käyttöönotosta. Tutkimuskysymykset olivat seuraavat: 1) missä määrin viljelijöiden intrinsiset ja ekstrinsiset eettiset arvot ohjaavat heidän päätöksentekoaan GM-kasvien käyttöönoton suhteen; ja 2) missä määrin sellaiset eettiset perusperiaatteet kuin pyrkimys hyvän tekemiseen, haitan tuottamisesta pidättäytyminen, reiluus ja oikeudenmukaisuus sekä valinnanmahdollisuus ja itsemääräämisoikeus toteutuvat viljelijöiden osalta heidän tehdessään GM-kasvien viljelyä koskevia valintoja ja päätöksiä? Aineistona oli 17 tieteellistä julkaisua vuosilta 1999-2006 yhdeksästä maasta. Suomesta ei ollut tutkimuksia saatavilla.

Viljelijöiden intrinsisiä arvoja suhteessa geeniteknologiaan ja GM-kasveihin oli selvitetty selvästi vähemmän kuin ekstrinsisiä, ja esimerkiksi luonnollisuus/luonnottomuus argumentti esiintyi vain yhdessä tutkimuksessa . Useimmissa maissa viljelijät olivat hyvin tietoisia GM-kasvien ruokaturvallisuuteen, ympäristövaikutuksiin, eläinten hyvinvointiin ja maatalouden rakennemuutoksiin liitetyistä näkökulmista. Uudessa-Seelannissa tehdyssä tutkimuksessa GM-myönteisten viljelijöiden eettinen arvopositio oli antroposentrisen (ihmiselle koituva hyöty)näkemyksen mukainen, kun taas luomuviljelijät sekä muut tavanomaista maataloutta edustavat viljelijät korostivat GM-kasveihin liittyviä riskejä. Eri maissa tuotetut viljelijätypologiat vastasivat hyvin toisiaan. Keskeiset asennetyypit olivat GMkasvien hyötyihin uskovat, riskien korostajat sekä fatalistit. Tavanomaista viljelyä edustavan viljelijäryhmän sisälläkin on siis arvoheterogeenisuutta suhteessa GM-kasveihin. Jopa GM-kasvit tuotantoon ottaneet viljelijät kyseenalaistivat ja uudelleenarvioivat tekemäänsä päätöstä jatkuvasti. Huolimatta todetusta heterogeenisyydestä asenne- ja arvotasolla, taloudelliset ja markkinatekijät määräsivät silti vahvasti viljelijöiden päätöksentekoa GM-kasvien käyttöönotosta. GM-kasveja koskevilla asenteilla ja arvoilla näytti olevan taipumusta muuttua myönteisemmiksi GM-kasvien käyttöönoton jälkeen, kun viljelystä kertyi kokemusta, mutta muutos myönteisempään suuntaan ei ollut yksiselitteistä kaikkialla. Eettinen yhteensopivuus on termi, joka tulisi liittää yhdeksi innovaation attribuutiksi tarkasteltaessa käyttöönottajien päätöksentekoon vaikuttavien tekijöiden merkitystä innovaation (esim. GM-kasvit) diffuusiolle.

Asiasanat: viljelijät, etiikka, intrinsiset arvot, ekstrinsiset arvot, muuntogeeniset kasvit, geenitekniikka, bioteknologia, kasvintuotanto, innovaatioiden diffuusio, asenteet, theory of planned behavior (TPB) 


\section{Johdanto}

Arvot ovat kognitiivisia konstruktioita, jotka selittävät yksilön elämälleen asettamia päämääriä, periaatteita ja käyttäytymisvalintoja (Renner 20003, 17). Eettiset arvot ovat perustavanlaatuisia vakaumuksia siitä, mikä on moraalisesti oikein tai hyvää ja mikä väärin tai pahaa (Vandeveer \& Menefee 2005). Intrinsiset arvot ovat päämääriä sinänsä, tavoiteltavia itsensä takia. Esimerkiksi kasvia voidaan pitää arvokkaana sen itsensä takia eikä siksi, että siitä on hyötyä ihmisille. Intrinsisten arvojen maailmaan kuuluvat esimerkiksi kysymykset geeniteknologian luonnollisuudesta/luonnottomuudesta (ks. Siipi 2008): geeniteknologia ja sen tuotteet voidaan arvottaa hyviksi tai pahoiksi sinällään ilman että ajatellaan niihin liittyviä hyötyjä tai riskejä. Ekstrinsiset arvot ovat instrumentaalisia arvoja: jotakin asiaa arvostetaan siksi, että sen avulla saavutetaan jotain hyvää, hyötyä tai muuta tavoittelemisen arvoista. (Zimmermann 2004). Muuntogeenisillä (GM) kasveilla voidaan nähdä olevan myönteistä ekstrinsistä arvoa, jos niiden avulla voidaan tuottaa hyötyä ihmisille, eläimille tai ekosysteemeille. GMkasvien vastustajat taas näkevät niissä ekstrinsisesti negatiivisia arvoja: GM-kasvien nähdään voivan vaikuttaa haitallisesti ympäristöön, ihmisiin, eläimiin sekä viljelijöiden toimeentuloon ja mahdollisuuksiin tehdä omien arvojensa mukaisia valintoja ammattiaan harjoittaessaan. (Comstock 2000).

Kun viljelijä tekee päätöstä ryhtyäkö viljelemään GM-kasveja vaiko ei, hän joutuu ratkaisemaan eettisen ongelman: kuinka arvottaa GM-kasveihin liitettyjä hyötyjä ja riskejä. Tässä päätöksentekotilanteessa (Launis 2006) viljelijän arvot saattavat osoittaa useampiakin kuin yhden vaihtoehdon, joiden välillä valita. Viljelijän elinkeinon harjoittamista koskevia päätöksiä ohjaavat sekä egoististaloudelliset että sosiaalis-moraaliset arvot (Chouinard et al. 2008). Näkyvä käyttäytyminen - päätös koskien GM-kasvien käyttöönottoa tai siitä luopumista - on seurausta viljelijän arvolähtöisestä päätöksentekoprosessista (Rokeach 1973). Päätöksentekoon liittyy sekä taloudellisia, teknisiä, sosiaalisia, poliittisia että eettisiä näkökohtia. Arvot voivat myös muuttua kokemuksen ja ulkopuolisten vaikutteiden ja voimien seurauksena (Fritsche 1991). Viljelijän päätöksentekoa tarkasteltaessa on siis ymmärrettävä myös tilannetekijöitä, joiden takia hän voi joutua tekemään kompromisseja eri arvojensa välillä (Hendrickson \& James 2005, Stuart 2009).

Kuluttajien eettisten arvojen vaikutusta heidän suhtautumiseensa muuntogeenisiin kasveihin on tutkittu paljon, mutta viljelijöiden on jostain syystä kohdistunut vähemmän mielenkiintoa ehkä siksi, että GM-myönteisten viljelijöiden katsotaan olevan teknologiasta potentiaalisesti hyötyvien joukossa. Viljelijät ovat GM-kasvien käyttöönotosta päättäessään kahden tulen välissä: yhtäältä heitä työntävät kohti teknologian käyttöönottoa sen potentiaaliset taloudelliset tai viljelytekniset hyödyt, toisaalta heidän on otettava huomioon kuluttajien GM-kasveja koskevat mielipiteet.

Kirjallisuustutkimuksen avulla perehdyttiin viljelijöiden eettisten arvojen rooliin heidän päättäessään muuntogeenisten kasvien viljelyn käyttöönotosta. Päätutkimuskysymys oli, missä määrin intrinsiset ja ekstrinsiset eettiset arvot ohjaavat viljelijöiden päätöksentekoa GM-kasvien käyttöönotosta. Lisäksi tarkasteltiin sitä, missä määrin sellaiset eettiset perusperiaatteet kuin hyvän tekemisen ja vahingon välttämisen periaatteet, reiluus ja oikeudenmukaisuus sekä valinnanmahdollisuus ja itsemääräämisoikeus toteutuvat viljelijöiden osalta heidän tehdessään ja toteuttaessaan GM-kasvien viljelyä koskevia valintoja.

\section{Aineisto ja menetelmät}

Aineistoksi etsittiin julkaisuja, joissa tutkittiin viljelijöiden arvoja, uskomuksia, näkemyksiä ja käyttäytymisvalintoja liittyen GM-kasvien käyttöönottopäätöksiin, viljelyyn ja hyväksyttävyyteen. Tässä tutkimuksessa keskityttiin läntisten teollisuusmaiden viljelijöiden eettisiin arvoihin yhtä poikkeusta lukuun ottamatta. Aineistoja julkaisutietokannoista (ISI Web of Science, Google Scholar, CAB Abstracts) etsittäessä päähakusanoina olivat seuraavat: farmer/grower ethics; ethics + transgenic crops /biotechnology /genetically modified crops /gmo crops; farmer/grower ethics + genetically modified crop/gmo/transgenic crop /biotechnology; farmer/grower + attitude/perception/belief/intention + genetically modified crop/gmo/transgenic crop /biotechnology. Lisäksi hyödynnettiin löydettyjen julkaisujen kirjallisuusluetteloita. Näillä kriteereillä ja hauilla aineistoksi löytyi 17 tieteellistä julkaisua vuo silta 1999-2006 yhdeksästä maasta (taulukko 1). Suomesta ei ollut tutkimuksia saatavilla. Suurin osa 
Taulukko 1. Julkaisut, joihin kirjallisuustutkimus perustui. E, J=tutkimus tehty ennen/jälkeen GM-kasvien viljelymahdollisuutta ko. maassa. KKT=kvalitatiivinen kyselytutkimus

\begin{tabular}{|c|c|c|c|}
\hline $\begin{array}{l}\text { Tutk.- } \\
\text { vuosi }\end{array}$ & $\begin{array}{l}\text { Maa (osa- } \\
\text { valtio) }\end{array}$ & Menetelmät. Teoreettinen viitekehys. Datan analysointimenetelmät. & Viite \\
\hline $1999 \mathrm{E}$ & AU & $\begin{array}{l}\text { KKT, } 193 \text { vastaajaa. Teoreettista viitekehystä ei mainita. Regressioanalyy- } \\
\text { si, Chi-neliötesti, korrelaatio. }\end{array}$ & 1 \\
\hline $1999 \mathrm{E}$ & NO & $\begin{array}{l}\text { KKT, } 430 \text { luomu- ja } 383 \text { tavanomaisen viljelyn harjoittajaa. Teoreettista } \\
\text { viitekehystä ei eksplisiittisesti mainittu. Binaarinen logistinen regressio. }\end{array}$ & 2 \\
\hline $2000 \mathrm{E}$ & NZ & $\begin{array}{l}\text { KKT, } 656 \text { vastajaa. Teoreettista viitekehystä ei mainita, Theory of Rea- } \\
\text { soned Action elementtejä ehkä taustalla. t-testi. }\end{array}$ & 3 \\
\hline $2002 \mathrm{E}$ & NZ & $\begin{array}{l}\text { KKT, } 115 \text { vastaajaa. Theory of Planned Behavior.(TPB). t-testi, korre- } \\
\text { laatio, MANOVA. }\end{array}$ & 4 \\
\hline $2002 \mathrm{E}$ & US (WA) & $\begin{array}{l}\text { KKT, } 598 \text { vastaajaa (109 luomu, } 489 \text { tavanomainen). Libertariaaninen, } \\
\text { utilitaristinen ja hyve-etiikka. Ristiintaulukointi. }\end{array}$ & 5 \\
\hline $\begin{array}{l}2002 \\
\text { alkaen } \mathrm{J}\end{array}$ & ES & $\begin{array}{l}\text { Kvalitatiiviset menetelmät, } 22 \text { ryhmä- ja yksilösyvähaastattelua. Toimin- } \\
\text { tatutkimus. Diskurssianalyysi. }\end{array}$ & 6 \\
\hline $2002 \mathrm{~J}$ & CA & $\begin{array}{l}\text { Eri menetelmiä: KKT, } 370 \text { vastaajaa, } 15 \text { syvähaastattelua kasvotusten, } 74 \\
\text { puhelinhaastattelua. Riskinäkemysteorian elementtejä viitekehyksenä. Kor- } \\
\text { respondenssianalyysi. }\end{array}$ & 7 \\
\hline $2003 \mathrm{~J}$ & US (MO) & $\begin{array}{l}\text { Etnografiset avoimet haastattelut, noin } 24 \text { tavanomaisen viljelyn harjoitta- } \\
\text { jaa. Teoreettista viitekehystä ei mainita. Haastattelujen subjektiivinen tul- } \\
\text { kinta. }\end{array}$ & 8 \\
\hline $2003 \mathrm{~J}$ & US $(\mathrm{OH})$ & $\begin{array}{l}\text { KKT, } 902 \text { vastaajaa (43.7\% viljelijöitä). Valittuja osia klassisesta dif- } \\
\text { fuusiomallista ja riskinäkemysteoriasta. Strukturoitu equation mallinnus. }\end{array}$ & 9 \\
\hline $2003 \mathrm{~J}$ & AU & $\begin{array}{l}\text { KKT, } 71 \text { vastaajaa. Innovaatioiden käyttöönoton teoria. Diskriminaatioana- } \\
\text { lyysi. }\end{array}$ & 10 \\
\hline $2004 \mathrm{E}$ & CA & $\begin{array}{l}\text { KKT, } 1566 \text { vastaajaa. Teoreettista viitekehystä ei mainita, riskinäkemysteo- } \\
\text { rian elementtejä ehkä taustalla. Faktorianalyysi, kvalitatiivinen data koodat- } \\
\text { tiin ja datasta todetut teemat yhdistettiin kvantitatiivisiin löydöksiin. }\end{array}$ & 11 \\
\hline $2004 \mathrm{E}$ & IN & $\begin{array}{l}100 \text { kasvotusten tehtyä haastattelua, avoimia ja suljettuja kysymyksiä. } \\
\text { Riskinäkemystoeria, jossa mukana riskien moraalinen komponentti. Te- } \\
\text { maattinen sisältöanalyysi. }\end{array}$ & 12 \\
\hline $2005 \mathrm{~J}$ & US (IL) & $\begin{array}{l}20 \text { avoimiin kysymyksiin perustuvaa haastattelua sekä KKT, } 200 \text { vastaajaa. } \\
\text { Teoreettista viitekehystä ei mainita, mutta riskinäkemysteorian aineksia } \\
\text { mukana. Diskurssianalyysi haastatteluille, järjestetty logistinen regression } \\
\text { KKT:lle. }\end{array}$ & 13 \\
\hline $2005 \mathrm{E}$ & $\begin{array}{l}\text { GB (Scot- } \\
\text { land) }\end{array}$ & $\begin{array}{l}\text { KKT soveltaen Q-metodologiaa, kasvotusten tehdyt haastattelut, vastaajien } \\
\text { lukumäärää ei ilmoiteta. Analysointi PQ-menetelmällä (korrelaatio, faktori- } \\
\text { analyysi, varimax rotaatio). }\end{array}$ & 14 \\
\hline $2005 \mathrm{E}$ & SE & $\begin{array}{l}\text { KKT, } 685 \text { vastaajaa. Teoreettista viitekehystä ei mainita. Korrelaatio- } \\
\text { analyysi, ei-parametriset testit, korrespondenssianalyysi, pääkomponentti- } \\
\text { analyysi. }\end{array}$ & 15 \\
\hline $2006 \mathrm{~J}$ & US & KKT, 692 vastaajaa. Kuvaileva etiikka. Pääkomponenttianalyysi. & 16 \\
\hline $\begin{array}{l}\text { 2003-05? } \\
\text { J }\end{array}$ & US (IL) & $\begin{array}{l}\text { KKT, } 134 \text { vastaajaa. Teoreettista viitekehystä ei mainita, innovaation käyt- } \\
\text { töönottoon vaikuttavien näkemysten teorian (adoption perception theory) } \\
\text { elementtejä taustalla. Chi-neliötesti, faktorianalyysi, binäärinen logistinen } \\
\text { regressio. }\end{array}$ & 17 \\
\hline
\end{tabular}

${ }^{1}$ McDougall et al. 2001, ${ }^{2}$ Storstad O, Bjørkhaug 2003, ${ }^{3}$ Fairweather \& Campbell, ${ }^{4}$ Cook \& Fairweather 2006, ${ }^{5}$ Glenna \& Jussaume 2007, ${ }^{6}$ Binimelis 2008, ${ }^{7}$ Mauro \& McLachlan 2008, ${ }^{8}$ James 2005, ${ }^{9}$ Napier et al. 2004, ${ }^{10}$ Crowe \& Pluske 2006, ${ }^{11}$ Mauro \& McLachlan 2009, ${ }^{12}$ Chong 2005, ${ }^{13}$ Guehlstorf 2008, ${ }^{14}$ Hall 2008, ${ }^{15}$ Lehrman \& Johnson 2008, ${ }^{16}$ James \& Hendrickson 2008, ${ }^{17}$ Chimmiri et al. 2006.

aineiston tutkimuksista perustui strukturoituihin kvantitatiivisiin kyselytutkimuksiin. Eettisten arvojen ja niistä nousevien uskomusten, näkemysten, aikomusten, päämäärien ja näkyvän käyttäytymisen välistä kausaalisuhdetta perustuen kognitiivisiin sosiaalipsykologisiin malleihin (ks. Fishbein \& Ajzen 1975, Ajzen 1991) hyödynnettiin vain yhdessä julkaisussa. Muissa tämä kausaalisuhde otettiin ilmeisesti oletettuna tai siihen ei otettu kantaa eikä mitään teoreettista viitekehystä esitetty tutkimuksen taustaksi, vaan se tehtiin gallup-kyselyn tapaisena. Aineisto oli siis laadultaan varsin heterogeenistä. 
Osa-aineistosta (10 julkaisua, 5 maata) tarkasteltiin ensin viljelijöiden suhtautumista GM-kasvien käyttöön kysymyksen "Ottaisitko käyttöön/hyväksytkö/söisitkö/viljeletkö ensi vuonna?” perusteella vastausvaihtoehtojen ollessa Kyllä, Ei ja En osaa sanoa/Ei mielipidettä. Seuraavaksi aineistosta etsittiin vihjeitä intrinsisten ja ekstrinsisten arvojen vaikutuksesta päätöksentekoon. Lopuksi tarkasteltiin, millaisia viljelijätypologioita oli todettu GM-kasveihin suhtautumisen perusteella.

\section{Tulokset ja tulosten tarkastelu}

\section{Asenneilmasto hyväksyn/en hyväksy -tyyppisesti luokiteltuna}

Kyllä/Ei/En osaa sanoa -tyyppiset vastaukset eivät välttämättä kerro niiden taustalla vaikuttavista eettisistä arvoista, vaan esim. taloudellisista, sosiaalisista tai teknisistä lähtökohdista. Viiden maan otoksessa (USA, Kanada, Australia, Uusi-Seelanti, Ruotsi) GM-kasvien käyttöön suhtautui myönteisesti 13-92,5 \% vastaajista ja kielteisesti 7,5-90 \%. Neutraaleja tai En tiedä-vastauksia oli 0-40\%. Otoksen perusteella on vaikea vetää muita johtopäätöksiä kuin että viljelijöiden suhtautuminen GMkasveihin vaihtelee huomattavasti riippuen maasta ja tilanteesta (esim. salliiko lainsäädäntö jo GMkasvien viljelyn vai ei, oliko viljelystä aikaisempaa kokemusta, onko kyse ravinto- vai rehukasvista).

\section{Intrinsisten ja ekstrinsisten arvojen vaikutus}

Vain kahdessa julkaisussa (Fairweather \& Campbell 2003, Hall 2008) oli tutkittu tai todettu eksplisiittisesti viljelijöiden intrinsisten eettisten arvojen vaikutusta GM-kasveihin suhtautumiseen. Hall (2003) ryhmitteli vastauksia skotlantilaisille viljelijöille esitettyihin avoimiin kysymyksiin. Vain yksi vastaus koski geeniteknologian luonnollisuus/luonnottomuus näkökulmaa.

Fairweather \& Campbell (2003) tutkivat Uuden Seelannin viljelijöiden eettisiä arvopositioita suhteessa GM-kasvien viljelyyn jakaen viljelijät ensin kolmeen ryhmään: luomuviljelijät, tavanomaisen viljelyn harjoittajat, jotka eivät aikoneet ottaa GM-kasveja käyttöön sekä GM-viljelyn käyttöönottoa harkitsevat. Vastaajat joutuivat ottamaan kantaa väitteisiin, jotka ilmensivät antroposentrismiä (ekstrinsinen luonnon arvotus), syväekologiaa, ekofeminismiä tai ekosentrismiä (intrinsinen luonnon arvotus). Kaikki ryhmät ilmensivät ainakin jossain määrin antroposentrismiä. Luomu- ja tavanomaisen viljelyn harjoittajiin vetosi ekofeministinen arvopositio samassa määrin, kun taas GM-myönteiset viljelijät eivät allekirjoittaneet sen periaatteita yhtä voimakkaasti. Syväekologinen ja ekosentrinen arvopositio erotteli luomu- ja GM-myönteiset ryhmät selvästi toisistaan. GM-myönteiset viljelijät olivat hekin kyllä ympäristötietoisia, mutta eivät yhtä painokkaasti kuin luomuviljelijät. Edelliset eivät pitäneet geeniteknologian käyttöön liittyviä ympäristöriskejä niin merkittävinä kuin luomuviljelijät. GMmyönteisten viljelijöiden taktiikka näytti olevan odottaa, kunnes geeniteknologian tuotteet kehittyvät sellaisiksi, että niiden avulla voidaan ratkaista maatalouteen liittyviä ympäristöongelmia ja ottaa kasvit käyttöön heti kun se olisi mahdollista (tutkimusajankohtana se ei vielä ollut). Norjalaiset viljelijät puolestaan eivät nähneet GM-kasveissa mahdollisuuksia maatalouden ympäristöongelmien ratkaisuun (Storstad O, Bjørkhaug 2003).

Luomuviljelijöiden ja tavanomaisen viljelyn harjoittajien välillä on muissakin tutkimuksissa löydetty eroja suhtautumisessa luontoon ja sen suojeluun sekä viljelijän rooliin maasta huolehtijana (Sullivan et al. 1996, Tybirk et al. 2004, Brodt et al. 2006). Tällaiset erot nousevat todennäköisesti eettisistä arvoista koskien elämää ja elämisen arvoja yleensä, ja ne heijastuvat myös viljelijän teknologisiin valintoihin (ks. myös Silvasti 2003 koskien käsityksiä hyvästä viljelijästä). USA:ssa Missouriosavaltion viljelijöitä tutkinut James (2005) päätteli, että etenkin taloudellisesti vaikeassa tilanteessa viljelijöiden eettiset pohdinnat painottuvat enemmän käyttäytymisen puolelle (kuinka menetellä lainja normien mukaisesti) kuin filosofiseen eettiseen pohdintaan (vrt. James 2003).

Kärjistetysti voisi olettaa, että luomuviljelijän harjoittaja hyväksyy viljelysuunnasta päättäessään jo etukäteen tietyn "eettisen paketin", johon hän sitoutuu yleisenä teknologisia ja muita valintoja ohjaavana periaatteena, kun taas tavanomaisen viljelyn harjoittajalla on enemmän eettisiä "vapausasteita” päättää teknologisista valinnoista tapauskohtaisesti joko periaatteellisten vakaumustensa tai taloudellisten hyötynäkökohtien perusteella. Luomuviljelyäkin voidaan kuitenkin harjoittaa myös taloudellisista perusteista lähtien, joten em. yleistyksen kanssa ei saisi mennä liian pitkälle. Ylipäätään viljelijän identiteettiä nimenomaan yrittäjänä määrittävät etenkin suhtautuminen taloudelliseen itsenäi- 
syyteen, tilan kasvuun ja voiton tavoitteluun (Vesala et al. 2007 ja sen viitteet). Suhtautumisessa näihin seikkoihin lienee eroja sekä tavanomaisen viljelyn harjoittajien että luomuviljelijöiden ryhmän sisällä. Aineistosta tuli ilmi, että myös luomuviljelijöiden keskuudessa oli kiinnostusta GM-kasvien käyttöä kohtaan, ja sama ilmeni myös Suomessa tehdyssä opinnäytetyössä (Pekkala 2003).

GM-myönteistenkin viljelijöiden tietoisuus GM-kasvien käyttöön yhdistetyistä potentiaalisista riskeistä tuli ilmi kaikissa tutkimuksissa paitsi yhdessä, joka oli tehty Intiassa (Chong 2005). Tämän perusteella ei ole tarkoitus yleistää, että Intian viljelijät ovat tietämättömiä geeniteknologiaan yhdistetyistä potentiaalisista riskeistä. Ko. tutkimus, jossa viljelijöiltä kysyttiin suhtautumista Bt-munakoison viljelyyn, valaisee kuitenkin hyvin sitä, että sosioekonomisista olosuhteista riippuen oletettujen riskien merkitys voi jäädä täysin ennakoitujen hyötyjen varjoon, jos hyödyt koetaan suuriksi. Proksimaaliseksi hyödyksi haastatellut viljelijät katsoivat ennen kaikkea mahdollisuuden tuottaa kannattavasti satoa ilman että kasvintuhoojat verottaisivat sitä yhtä paljon kuin normaalisti, mutta hyötynäkemys ulotettiin myös munakoisoja ostaviin asiakkaisiin, joiden altistuminen kemiallisten torjunta-aineiden jäämille vähenisi. Mainittakoon, että Bt-munakoiso ei ollut tutkimuksen ajankohtana viljelyssä Intiassa.

Länsimaiden viljelijöiden suhtautumista GM-kasveihin määrittävät aineiston perusteella ennen muuta tilatason potentiaaliset tai koetut hyödyt. Ekstrinsiset arvot siis määrittävät voimakkaasti potentiaalisia tai toteutuneita valintoja niillä viljelijöillä, jotka viljelyjärjestelmän puitteissa voivat valita GM-kasvien viljelyn. Samanaikaisesti viljelijät silti tiedostavat myös GM-kasveihin liitettyjä potentiaalisia ympäristö- ja terveysriskejä. Tämä on tietysti itsestään selvää sikäli, että toteutuessaan ne haittaisivat tuotteiden markkinoille saamista. USA:n viljelijöiden keskuudessa GM-kasvien viljelyn kokeminen eettiseksi vahvistui maissin ja soijan viljelystä kertyneen kokemuksen myötä (Chimmiri et al. 2006). Sen sijaan Kanadassa GM-canolan viljelijöiden kokemukset eivät heijastuneet myönteisenä suhtautumisena markkinoille aiottuun GM-vehnään (Mauro \& McLachlan 2008, Mauro et al. 2009). Syynä olivat ennen kaikkea kontaminaatiotapaukset, joissa GM-canolan siitepölyä oli kulkeutunut naapurien pelloille (ks. myös Knispel \& McLachlan 2009). Yhteisölliset ja sosiaaliset seikat selittivät kuitenkin vain pienen osan canolan viljelyyn yhdistetyistä riskinäkemyksistä. Tlatasoisset taloudelliset riskit olivat etusijalla. GM-vehnän kehittämiseen ja viljelykokeisiin suhtauduttiin sen vuoksi negatiivisesti, ja viljelijät kokivat, että heiltä pimitettiin tietoa liittyen siitepölyn kulkeutumiseen ja tavanomaisten siemenerien sekoittumismahdollisuuteen GM-vehnän siementen kanssa. He kokivat,että heidän kokemustietoaan GM-canolan viljelystä ei huolittu osaksi GM-vehnän markkinoilletuonti- ja säätelyprosessia. Vastaavanlaisia kokemuksia GM-kasvien viljelijöiden kokemustiedon huomiotta jättämisestä raportoi myös Guehlstorf (2008) USA:sta. Reiluuden ja itsemääräämisoikeuden toteutumatta jäämisen kokemuksia on ollut myös espanjalaisilta maissinviljelijöiltä, joiden pellot ovat kontaminoituneet GM-maissilla. He eivät aina halunneet nostaa sinänsä mahdollista syytettä asiasta, koska arvottavat naapurisovun korkeammalle kuin viljelystensä geneettisen puhtauden menetyksen (Binimelis 2008).

\section{Viljelijätypologiat GM-kasvien viljelyyn suhtautumisen mukaan}

Skotlannissa, Uudessa Seelannissa, Ruotsissa ja Australiassa tehdyissä tutkimuksissa viljelijät voitiin karkeasti ryhmitellä neljään ryhmään sen mukaan, miten he suhtautuivat GM-kasveihin. GMmyönteiset viljelijät korostivat GM-kasvien ekstrinsisiä positiivisia arvoja, ja heidän päätöksentekoaan motivoivat ennen kaikkea tilatasoiset oletetut tai koetut taloudelliset hyödyt. Riskejä painottavat viljelijät sen sijaan kohdistivat GM-kasveihin selvän negatiivisia ekstrinsisiä arvoja. He olivat kuitenkin valmiita, tosin vastahakoisesti, ottamaan GM-kasvit käyttöön, jos niistä saatava taloudellinen hyöty olisi välttämätöntä elinkeinon kannattavuudelle, mutta heidän huolensa kuluttajien reaktioista GMkasveihin oli silti suurempi kuin ensimmäisellä ryhmällä. Kolmas ryhmä olivat fatalistit, jotka eivät katsoneet voivansa vaikuttaa geeniteknologian rooliin elinkeinonsa harjoittamisessa millään tavalla, vaan tavallaan alistuivat enemmistön päätökseen. Neljännen ryhmän muodostivat GM-kasvien viljelyyn kielteisesti suhtautuvat viljelijät, joista luomuviljelijät todennäköisesti perustelevat kantaansa muita useammin sekä instrinsisillä että ekstrinsisillä, riskejä korostavilla syillä, kun taas tavanomaista viljelyä edustavilla riskien korostaminen saattaa määrätä suhtautumista voimakkaimmin. "Vastahakoisten käyttöönottajien” ryhmästä löytynee eniten niitä viljelijöitä, jotka joutuvat tekemään arvokompromisseja päättäessään, ottaako GM-kasvit viljelyyn omalla tilalla vai ei.

Viljelijöitä on typologisoitu myös heidän yleisten viljelytavoitteidensa ja arvojensa perusteella (esim. Garforth \& Rehman 2006), jolloin on havaittu sellaisia ryhmiä kuin perhesuuntautuneet, yrittä- 
jän identiteetin omaavat, harrasteviljelijät, elämäntapaviljelijät ja itsenäiset pienen tilakoon viljelijät. Ammattiin liittyvissä arvoissa ja motiiveissa on eroja näiden ryhmien välillä, joten myös GM-kasvien eettinen arvottamisessa saattaa olla eroja ryhmien välillä.

\section{Johtopäätökset}

Tiivistettunä vastauksena ensimmäiseen tutkimuskysymykseen: kyllä, sekä intrinsisiset että ekstrinsiset arvot vaikuttavat taustalla, kun viljelijä tekee päätöstä GM-kasvien käyttöönotosta. Ekstrinsiset hyötyjä tai riskejä korostavat arvot vaikuttavat viljelijöiden päätöksiin voimakkaasti, mutta viljelijät eivät ole tässä suhteessa homogeeninen ryhmä. Taloudellisia, tilakohtaisia seurauksia korostavat näkemykset dominoivat päätöksenteon taustalla niillä viljelijöillä, jotka voivat ainakin periaatteellisella tasolla päättää joko GM-kasvien käyttöönoton puolesta tai vastaan. Intrinsisten arvojen merkitys saattaa olla suurempi luomuviljelijöillä ja myös osalla tavanomaisista viljelijöistä, jotka kieltäytyvät GMkasvien käytöstä, mutta heterogeenisyyttä esiintynee tässäkin suhteessa sen mukaan, miten bisnesorientoitunut viljelijä on ja miten voimakas yrittäjän identiteetti hänellä on. Tästä ei kuitenkaan ollut eksplisiittisesti tuloksia saatavissa, koska kiinnostus viljelijöiden intrinsisiä arvoja kohtaan kuten yleensäkin viljelijöiden GM-etiikkaan suhteessa kuluttajista tehtyjen tutkimusten määrään näyttää olleen vähäistä. GM-kasveja koskevat arvot voivat muuttua viljelykokemuksen kertymisen myötä, ja esimerkkejä on muuttumisesta sekä negatiivisempaan että positiivisempaan suuntaan. Kulttuuritausta eli yhteiskunnan yleinen suhtautuminen GM-kasveihin vaikuttanee tässä, mutta viljelijälle kertyvän kokemusperäisen tiedon merkitystä ei tule vähätellä ja hänen tämänkaltainen tietämyksensä tulisi saada paremmin osaksi GM-kasvien markkinoilletuonti- ja säätelyprosesseja. Johdannossa mainitut eettiset perusperiaatteet eivät kaikilta osin aina toteudu viljelijöiden osalta, ja sekä GM-kasvien viljelijät että perinteisellä jalostuksella tuotettujen kasvien viljelijöillä on tästä kokemuksia. Itsemääräämisoikeuden toteutumatta jäämisestä on selkeitä esimerkkejä maista, joissa viljellään helposti siitepölynä tai siemeninä leviäviä GM-kasveja ja ne päätyvät ei-GM-pelloille. Yksityiskohtaisempi tarkastelu tässä kirjoituksessa esitetystä kirjallisuustutkimuksesta löytyy julkaisusta Vänninen et al. (2009).

\section{Kirjallisuus}

Ajzen, I. 1991. The theory of planned behaviour. Organizational Behavior and Human Decision Process 50: 179211.

Binimelis, R. 2008. Coexistence of plants and coexistence of farmers: is an individual choice possible? Journal of Agricultural and Environmental Ethics 21: 437-57.

Brodt, S., Klonsky, K., Tourte, L. 2006. Farmer goals and management styles: implications for advancing biologically based agriculture. Agricultural Systems 89: 90-105.

Chimmiri, N., Tudor, K.W., Spaulding, A.D. 2006. An analysis of McLean County, Illinois farmers' perceptions of genetically modified crops. AgBioForum 9(3): 152-65.

Chong, M. 2005. Perception of the risks and benefits of Bt egg-plant by Indian farmers. Journal of Risk Research 8: 617-34.

Chouinard, H.H., Paterson, T., Wandschneider, P.R., Ohler, A.M. 2008. Will farmers trade profits for stewardship? Heterogeneous motivations for farm practice selection. Land Econ 84(1): 66-82.

Comstock, G. 2000. Vexing Nature: On the ethical case against agricultural biotechnology. Dordecht, NL: Springer.

Cook, A.J., Fairweather, J.R. 2006. New Zealand farmer and grower intentions to use gene technology: Results from a resurvey. AgBioForum 6(3): 120-27.

Crowe, B., Pluske, J. 2006. Will genetically modified canola be adopted in WA? Australasian Agribusiness Review 14, Paper 7: 1-12.

Fairweather, J.R., Campbell, H.R. 2003. Environmental beliefs and farm practices of New Zealand farmers: Contrasting pathways to sustainability. Agriculture and Human Values 20: 287-300.

Fishbein, M., Ajzen, I. 1975. Belief, attitude, intention and behaviour: an introduction to theory and research. Reading, MA: Addison-Wesley.

Fritzsche, D.J. 1991. A Model of decision-making incorporating ethical values. Journal of Business Ethics 10: 841-52.

Garforth, C., Rehman, T. 2006. Behavioural Typology of Farmers in England. [online] Project report no. 7. Research project EPES 0405/17 "Research to understand and model the behaviour and motivations of farmers in responding to policy changes (England)". School of Agriculture, Policy and Development, Department for 
Environment, Food and Rural Affairs, University of Reading. [Siteerattu 24.6.2009] Saatavissa netissä: https://statistics.defra.gov.uk/esg/reports/farmer\%20behaviour/Annex\%20H\%20Farmer\%20Behaviour\%20re port\%207\%20Typology.pdf..

Glenna, L.L., Jussaume, R.A. 2007. Organic and conventional Washington State farmers' opinions on GM crops and marketing strategies. Renewable Agricultural and Food Systems 22: 118-24.

Guehlstorf, N.P. 2008. Understanding the scope of farmer perceptions of risk: considering farmer opinions on the use of genetically modified (GM) crops as a stakeholder voice in policy. Journal of Agricultural and Environmental Ethics 21: 541-58.

Hall, D. 2008. Identifying farmer attitudes towards genetically modified (GM) crops in Scotland: Are they proor anti-GM? Geoforum 39: 204-12.

Hendrickson, M.K., James, H.S. Jr. 2005. The ethics of constrained choice: How the industrialization of agriculture impacts farming and farmer behaviour. Journal of Agricultural and Environmental Ethics 18: 269-91.

James H.S. Jr. 2005. On finding solutions to ethical problems in agriculture. Journal of Agricultural and Environmental Ethics 16: 439-457.

James, H.S. Jr, Hendrickson, M.K. 2008. Perceived economic pressures and farmer ethics. Agricultural Economy 38: 349-61.

James, HS, Jr. 2005. The ethical challenges in farming: a report on conversations with Missouri corn and soybean producers. Journal of Agricultural Safety and Health 11(2): 239-48.

Knispel, A.L., McLachlan, S.M. 2009. Landscape-scale distribution and persistence of genetically modified oilseed rape (Brassica napus) in Manitoba, Canada. Environmental Science \& Pollution Research. [e-Publ before print]

Launis, V. 2003. Geeniteknologia, arvot ja vastuu. Helsinki: Gaudeamus.

Lehrman, A., Johnson, K. 2008. Swedish farmers attitudes, expectations and fears in relation to growing genetically modified crops. Environmental Biosafety Reseach 7: 153-62.

Mauro, I.J., McLachlan, S.M. 2008. Farmer knowledge and risk analysis: postrelease evaluation of herbicidetolerant canola in Western Canada. Risk Analysis 28(2): 463-76.

Mauro, I.J., McLachlan, S.M., Van Acker, R.C. 2009. Farmer knowledge and a priori risk analysis: pre-release evaluation of genetically modified Roundup Ready wheat across the Canadian prairies. [online] Environmental Science \& Pollution Research 16:689-701.

McDougall, D.J., Longnecker, N.E., Marsch, S.P., Smith, F.P. 2001. Attitudes of pulse farmers in Western Australia towards genetically modified organisms in agriculture. Australasian Biotechnology 11: 36-9.

Napier, T.L., Tucker, M.A, Henry, C., Yang, X. 2004. Ethical orientations of Ohio residents toward genetically engineered plants and animals: An urban/rural comparison. Food and Agricultural Environment 2(2): 400411.

Pekkala, H. 2003. Luonnonmukaisen kasvituotannon ja muuntogeenisten kasvien rinnakkaiselo sekä suomalaisen luomuviljelijän käsitykset siitä. Opinnäytetyö. Laurea ammattikorkeakoulu, Hyvinkää-instituutti. 108 s.

Renner, W. 2003. Human values: A lexical perspective. Personal and Individual Differences 34: 127-41.

Rokeach, M. 1973. The nature of human values. New York: The Free Press.

Siipi, H. 2008. Dimensions of naturalness. Ethics \& the Environment 13(1): 71-103.

Silvasti, T. 2003. The cultural model of "the good farmer" and the environmental question in Finland. Agriculture and Human Values 20(1): 143-50.

Storstad, O., Bjørkhaug, H. 2003. Foundations of production and consumption of organic food in Norway: Common attitudes among farmers and consumers? Agriculture and Human Values 20: 151-63.

Stuart, D. 2009. Constrained choice and ethical dilemmas in land management: Environ quality and food safety in California agriculture. Journal of Agricultural and Environmental Ethics 22: 53-71.

Sullivan, S., McCann, E., de Young, R., Erickson, D. 1996. Farmers' attitudes about farming and the environment: a survey of conventional and organic farmers. Journal of Agricultural and Environmental Ethics 9(2): 123-43.

Tybirk, K., Alroe, H.F., Frederiksen, P. 2004. Nature quality in organic farming: a conceptual analysis of considerations and criteria in a European context. Journal of Agricultural and Environmental Ethics 17: 249-74.

Vandeveer, R.C., Menefee, M.F. 2005. Human Behavior in Organizations. Pearson Prentice Hall.

Vesala, K.M, Peura, J., McElwee, G. 2007. The split entrepreneurial identity of the farmer. Journal of Small Business and Enterprise Development 14(1): 48-63.

Vänninen, I., Siipi, H., Keskitalo, M., Erkkilä, M. 2009. Ethical compatibility of GM crops with intrinsic and extrinsic Values of farmers: A review. The Open Ethics Journal 3: 104-117.

Zimmerman, M.J. 2004. Intrinsic versus extrinsic values. In: Zalta, E.N. (ed), The Stanford Encyclopaedia of Philosophy. [Siteerattu 7.6.2009] Saatavissa netissä: http://plato.stanford.edu/archives/fall2004/entries/valueintrinsic-extrinsic/. 